Giving the gift of goodness: An exploration of socially responsible gift-giving Subject Matter: Marketing and Consumer Behavior 


\begin{abstract}
Previous research demonstrates that consumers support firms' CSR activities, and increasingly demand socially responsible products and services. However, an implicit assumption in the extant literature is that the purchaser and the consumer of the product are the same person. The current research focuses on a unique form of socially responsible consumption behavior: giftgiving. Through thirty depth consumer interviews, we develop a typology of consumers based on whether consumers integrate CSR-related information into purchases, and whether the purchases are for themselves or for others (i.e., gifts). We find that in some instances, consumers actively avoid purchasing products from socially responsible organizations and do so with the intention of managing their impressions with the gift recipient. This is counter to previous research that suggests consumers often choose to make socially responsible consumption decisions in efforts to satisfy self-presentation concerns. In addition, the decision to engage in socially responsible consumption for oneself but not for others was motivated by a variety of factors including the role of the recipient and a concern over the credibility of socially responsible gifts. Finally, some participants who do not incorporate CSR into their own personal consumption chose gifts based on a variety of CSR activities in an effort to build awareness for socially responsible organizations.
\end{abstract}

Keywords: Consumer behavior, corporate social responsibility, gift-giving, interviews qualitative. 


\section{Giving the gift of goodness: An exploration of socially responsible gift-giving.}

"If I'm buying a gift for a friend and I'm trying to impress them and if it's a good gift and it works well, it has great attributes and it's from a socially responsible company, it's environmentally friendly and all this stuff, there's more of a chance that they'll be happy with the gift because all of the different criteria are covered."(Male, 28)

Although there is increasing consumer demand for products and services that are marketed by socially responsible firms (2013 Cone Communications/Echo Global CSR Study) an implicit assumption of previous academic research is that the purchaser of these products and services is also the consumer. For example, Peloza and Shang (2011) perform a systematic review of the corporate social responsibility (CSR) literature and categorize different forms of consumer value created by CSR activities. They conclude that although some forms of CSR activities allow consumers to derive social value from their consumption, this social value comes from ones own consumption (e.g., driving a Prius communicates to others one's concern for the environment). Within the extant CSR literature, the importance of social responsibility on purchases intended as gifts remains unstudied. Similarly, the literature examining gift-giving includes the role of the social dimensions of gifts such as self-presentation concerns (e.g., Belk 1984; Segev et al. 2012), and the self-symbolism of gifts (i.e., Wolfinbarger et al. 1996), but does not include an examination of the role of CSR or ethical attributes.

The opening quote, from data generated for this study, supports the assertion that CSRrelated attributes can play an important role in the in the gift-giving decision making process. Consequently, the aim of this paper is to explore socially responsible consumption behavior in the gift-giving context. Specifically, we establish the role of CSR in symbolic exchange and develop a typology of consumers based on the integration of CSR-related information associated 
with decision-making for consumers' own personal consumption and when buying for others (i.e., gifts).

Through our examination, we make a number of contributions to an important and emerging area of CSR-related consumption behavior that has received very little attention in the research to date. First, while, previous researchers have developed consumer typologies based on general consumer expectations for firms to engage in socially responsible activities (Mohr et al. 2001) and how consumers respond to specific CSR activities such as cause-related marketing campaigns (Webb and Mohr 1998), this current study is innovative as it explores the role of socially responsible consumption via gift-giving (i.e., buying for others). This in turn supports the development of a typology based on differences in personal consumption decisions and giftgiving decisions. Interestingly, recent research (Cone Inc. 2012) notes that consumers often consider socially responsible dimensions in their gift giving decisions. Over $70 \%$ of consumers surveyed not only expect companies to support charitable causes during seasonal holiday campaigns (e.g. Christmas, Thanksgiving etc.) but are more likely to feel better about supporting companies that provide donations to charitable organizations during seasonal or ritual holidays. Accordingly, the current research provides a foundation from which to examine socially responsible gift-giving by identifying key themes that influence personal consumption and giftgiving decisions in order to better understand this area of growing interest amongst consumers.

Second, socially responsible consumption behavior (SRCB), defined as "a person basing his or her acquisition, usage and disposition of products on a desire to minimize or eliminate any harmful effects and maximize the long-term beneficial impact on society" (Mohr et al. 2001; p. 47) is rising in importance amongst consumers. However, previous research demonstrates that consumers who engage in some form of socially responsible consumption behavior do not 
necessarily behave uniformly. For example, Peattie (2001) notes that consumers who recycle do not necessarily engage in other environmentally-friendly behaviors such as purchasing green products or seeking reusable products. Szmigin et al. (2009) similarly report that even consumers who self-identify as socially conscious engage in flexible consumption behavior and do not factor ethics and social responsibility across all of their consumption decisions. We introduce a novel socially responsible consumption behavior. Rather than a focus on consistency across various types of socially responsible consumption behavior, we examine the consistency (or lack thereof) across purchase decisions made for personal use versus those made for others (i.e., gifts). Specifically, within our typology, we identify two segments of consumers who make inconsistent purchase decisions based on whether they are purchasing for themselves or for others, and identify a variety of factors that lead to this inconsistency.

Third, while previous research suggests that the attitude-behavior gap is a significant impediment to socially responsible consumption behavior (i.e., Carrigan and Attalla 2001; Peattie and Crane 2005), we identify a segment of consumers who, despite not holding positive attitudes towards socially responsible consumption behavior, purchase socially responsible items for others (i.e., gifts). Further, we provide evidence that even consumers who do not include CSR-related information in their own personal consumption decisions still seek to develop awareness amongst others through their gift-giving. Thus, our study of the role of CSR in giftgiving is essentially the attitude-behavior gap in reverse order, where a stated lack of concern for CSR activities nonetheless corresponds to support for such activities. In addressing this gap, the current study finds that the gift-giving process is one means by which consumers become more aware of CSR initiatives, which could serve to address low levels of awareness of CSR activities among consumers (Carrigan and Attalla 2001; Du et al. 2007; Peloza et al. 2012). 
Finally, extant research suggests that consumers will often purchase products from firms with positive reputations for CSR as a way of managing their impressions on others (Yoon et al. 2006). For example, Griskevicius and colleagues (2010) found that consumers are motivated to select environmentally friendly products when making decisions in front of others, even at the risk of selecting a product that is perceived to be of lower quality. However, we identify an important boundary condition on prior research as we find that some consumers within our sample will actually avoid purchasing socially responsible gifts for others in an effort to manage impressions with the recipient of the gift. This research explores the extent to which impression management influences the choice of gift for the recipient.

The paper proceeds as follows. Firstly, we present reviews of both the CSR and giftgiving literatures to provide the relevant background that informed our research question and interview protocol. Building on these concepts, this study employs a qualitative, interpretive approach and reports data from 30 in-depth interviews with a diverse group of respondents from multiple cities across North America. Next, we present the results from our interviews across a variety of emergent themes. Finally, we present discussion and implications for researchers as well as practitioners.

\section{Literature Review}

The following section outlines the literature examining the influence of CSR activities on consumer purchase decision-making behavior, and identifies the ways in which CSR-related products provide value to consumers. The social value of gift-giving is recognized and its potential inter-relationship with the social value of CSR examined. This affords consideration of 
the proposed integration of CSR information on purchase decisions made in relation to giftgiving.

The Influence of CSR Activities on Consumers

Since our interest lies in the influence of CSR activities on consumer decision-making, we adopt Barnett's (2007, p. 801) definition of CSR as “a discretionary allocation of corporate resources toward improving social welfare that serves as a means of enhancing relationships with key stakeholders." This definition incorporates the primary business case justification for investments in CSR activities by managers - the promise of enhancing relationships between customers and their brands (Haanaes et al. 2011). Moreover, the categorization of CSR activities used by Peloza and Shang (2011) identifies four distinct categories that provide different sources of value to consumers: philanthropy (e.g., donations to charity, employee volunteerism, causerelated marketing campaigns), business practices (e.g., emissions reduction through production processes, environmentally friendly supply chain practices), self-oriented product-related (e.g., energy efficiency of products when consumed, health benefits associated with organic foods), and other-oriented product-related (e.g., environmental benefits of organic foods, environmental benefits of fuel efficient vehicles). The current research seeks to better understand the types of activities that our participants associate with CSR and how these activities influence both personal and gift-giving decisions.

Existing research provides a number of ways in which CSR activities enhance relationships with consumers, such as increased trust and loyalty towards retailers (Castaldo et al. 2009), as well as a disposition to pay higher prices for products (Laroche et al. 2001; De Pelsmacker et al. 2005). Additional outcomes include greater purchase intentions (e.g. Mohr and 
Webb 2005) and a willingness to engage in positive word-of-mouth on behalf of firms (e.g. Hoeffler and Keller 2002). Despite the strong evidence suggesting consumers both support and reward firms' CSR engagement, consumer support for CSR activities is equivocal for a variety of reasons including a lack of awareness of firms' CSR activities (i.e., Du et al. 2007; Pomering and Dolnicar 2009) and a general reluctance to sacrifice quality in favor of CSR attributes (i.e., Auger et al. 2008).

Interestingly, although consumers may have positive attitudes towards socially responsible consumption, this is not always evident in their behavior. This attitude-behavior gap is defined by Valor (2008, p. 316) as "a gap between the self-reported intention of buying responsibly and the evidence that this intention does not translate into personal behavior." Similarly, Peattie and Crane (2005) observe that green marketing has also suffered as a result of the significant gap between concern and actual purchasing behavior. This suggests that while consumers may feel positively about CSR-related products that can be purchased as gifts, this may not translate into consumption. Indeed, the inherent symbolic role of gift-giving may preclude integrating CSR information when purchasing gifts. This will be examined here.

Finally, consumers change their behaviors based on social influences across a variety of socially responsible consumption behaviors including the evaluation of environmentally friendly products (i.e., Griskevicius et al. 2010), charitable donations (i.e., White and Peloza 2009) and cause-related marketing campaigns (i.e., Youn and Kim 2008). What is unknown in this context is how, and in what ways, CSR attributes affect gift purchases.

The Social Value of Gift-giving 
The exchange of gifts is defined as a "social activity confirming relationships and social interactions" (Hollenbeck et al. 2006, p.573). Wolfinbarger and Gilly (1996) suggest that gifts extend beyond the economic function of the object and become representations and extensions of both the gift giver and receiver. As a consequence, gift-giving is a more involving process than making purchases for personal use (Belk, 1982). Belk (1982) also suggests that a variety of factors influence the level of involvement of the gift-giving decision-making process including characteristics of the gift, the consideration of the recipient of the gift and the reason why the gift is being purchased (i.e., the occasion).

Gift givers are aware that their gifts will be evaluated by the recipient. In fact, Parsons (2002) suggests that gift recipients make assessments of the relationship between themselves and the gift giver based on the gift purchased for them. Due to the highly visible and unique social nature of gift-giving, researchers observe that gifts provide an opportunity for gift givers to manage their impressions with the recipients (Segev et al. 2012). The impression management literature suggests that in general, individuals seek to make a favorable impression on others and to present themselves in a positive light (i.e., Leary and Kowalski 1990). Similarly, Ratner and Kahn (2002) note that when consumers expect others will evaluate their actions (i.e., consumption behavior) they alter their decisions in order to present the desired impressions to others.

\section{The Social Value of CSR}

Similar to gift-giving, the social value consumers receive from engaging in socially responsible consumption behavior manifests itself a variety of ways including: impression management, self-enhancement, affiliation with aspirational reference groups and the 
communication of one's identity to others. For example, consumers are aware that their support for firms that promote environmental initiatives can be used as a way of defining oneself to the community (Green and Peloza 2011). Goldstein et al. (2008) also posit that by being recognized as someone who expresses concern for the environment and engages in environmentally friendly consumption, consumers can ensure they meet the existing social norms and community standards that reinforce the behavior. These examples support the seminal work of Sheth et al. (1991) who note that cumulative value across functional, emotional and social dimensions predicts consumption behavior.

Consistent with the impression management literature, consumers' preference for environmentally friendly products increase when their consumption decisions are made in the presence of others (Griskevicius et al. 2010; Basil and Weber 2006). Youn and Kim (2008) also suggest that consumers purchase products from firms that support social causes in an effort to enhance their identity to others. The current research explores whether and how these differing types of social value (e.g. impression management, affiliation etc.) associate with and influence socially responsible consumption behavior through the social and symbolic context of gift purchases.

Researchers also suggest that specific types of products provide greater opportunity for consumers to experience the social value associated with CSR activities. Youn and Kim (2008), for example, suggest that demand for publicly visible products is enhanced through cause-related marketing campaigns, because publicly self-conscious consumers are more receptive to these campaigns. In addition, Peloza and Shang (2011) note that symbolic products provide consumers with an opportunity to express their social identity to others. Specifically, through the purchase of socially responsible products, consumers are afforded the opportunity to publicly express their 
support for a social or environmental issue. Supporting this notion, the gift-giving literature also recognizes the importance of gifts being used in order to communicate identity to others. For example Schwartz (1967, p. 1) notes: "gifts are one of the ways in which pictures that others have of us in their minds are transmitted." In sum, although the motives behind gift-giving and support for CSR activities share many commonalities, researchers have yet to explore these behaviors in concert.

\section{Qualitative Research Approach}

Since the role of socially responsible consumption in gift-giving is relatively unexplored, qualitative depth interviews served as an appropriate methodology (Strauss and Corbin, 1990). In addition, the goal of our research is discovery-oriented and we sought to examine a variety of factors that influence socially responsible gift-giving. Similar qualitative methods have been used by researchers examining consumer behaviors related to CSR activities (e.g., Carrigan and Attalla 2001; Mohr et al. 2001; Oberseder et al. 2011). Additionally, qualitative research methods can provide an important sense of realism to the examination of consumer responses to CSR (Arnold et al. 1996). Finally, previous research that has developed consumer typologies based on the consumer response to both CSR in general (Mohr et al. 2001) and those considering cause-related marketing campaigns (Webb and Mohr 1998) have followed a similar exploratory, qualitative approach. Building on these previous efforts, our typology differs in that we examine the consumer response across both personal consumption and gift-giving decisions. Additionally, our examination includes a wide-variety of CSR activities that influence our participants' consumption patterns rather than a focus on a specific CSR activity (i.e., cause-related marketing campaigns). 


\section{Data Collection}

In order to overcome the potential for socially desirable responses, we provided the participants the option of being interviewed at either their homes or their workplace in order to allow them to feel comfortable. In addition, the participants were reminded that we sought their honest opinions and there were no right or wrong answers (Oberseder et al. 2011). The fact that a number of participants suggested that CSR was not a significant consideration for their purchase decisions, either for themselves or when purchasing gifts, suggests a level of comfort and trust was established between the authors and interviewees. In addition, a number of projective techniques were also used and included asking the participants to assign personality traits to brands they perceive to be socially responsible. The participants were also asked to explain the importance of CSR-related product attributes compared to more traditional product attributes such as price, quality and reliability. Further, participants were asked to compare the importance of socially responsible consumption behavior regarding purchases made for their own personal use with purchases made as gifts for others (Donoghue 2000). Finally, the interview participants were asked to provide actual consumption decisions related to CSR - both for purchases for their own use and for purchases for others (gifts) in order to address the potential for socially desirable responding.

The semi-structured interview guide (see Appendix 1) was developed through the review of the existing CSR and gift-giving literatures. The questions provided some organization to the interview, although often follow-up questions were used when participants wished to elaborate on initial answers. As suggested by Miller and Crabtree (1992), the use of a semi-structured interview guide allows participants to situate the influence of CSR activities through actual 
consumption experiences and gift-giving decisions. The initial set of questions in the interview guide allowed for discussion of general consumption behavior including the attributes considered when making purchases. Next, participants were asked to identify examples of activities that firms are currently engaged in that make them appear to be socially responsible. In addition, specific questions related to personal consumption of socially responsible products and services for their own personal use were asked, followed by questions about purchases for others.

The thirty interviews averaged 35 minutes in length and were recorded and transcribed verbatim. In sum, 334 pages of transcripts were reviewed individually along with accompanying field notes taken during the interview process in order to better understand how corporate social responsibility influenced gift-giving decision-making. The interview data was sufficient to ensure saturation (Guest et al. 2006).

\section{Interview Sample}

The participants were recruited from multiple cities across North America including New York, Boston, Toronto and Vancouver. Initial sampling was conducted by asking colleagues for referrals, and subsequent sampling was managed through snowballing. This follows the approach adopted by previous work examining consumer behavior in the context of CSR (i.e., Brunk 2010; Oberseder et al. 2011). The early participants who provided introductions to potential interviewees were instructed to not disclose the purpose of the research in order to avoid the potential for biases being introduced prior to the interview.

The demographics of the sample are summarized in Table 1 and represent a diverse population. In total, 16 males and 14 females were interviewed ranging in age from 22 to 57 years old, with an average age of 34 years. The participants worked across a wide variety of 
industries including education, healthcare, beauty and wellness, publishing, not-for-profit, financial services and insurance and land development. The informants also varied across occupation type (i.e., senior management, middle management and administrative function), income level and marital status.

\section{Data Analysis}

The transcripts were reviewed separately by the authors followed by discussion of each individual transcript, reflecting the iterative process suggested by Spiggle (1994). The initial discussions between the authors resulted in updates of the interview protocol based on emerging themes in the data. In addition, the interview guide was altered based on discussion between the authors regarding how participants perceived the questions during the interviewing process (Mohr et al. 2001). Post-interview discussion with participants resulted in both the addition of new questions and the alteration of existing questions that proved difficult for the interviewees. Further, data analysis followed the recommended iterative approach of reading, coding, discussion regarding the coding amongst the authors and re-reading the transcripts in whole (Glaser and Strauss 1967).

The coding of the interviews was threefold. As our interest lies in better understanding the role of CSR in gift-giving and how the context of buying for others influences consumers' decision making, we coded each transcript in order to develop a typology of consumers within the sample. Specifically, each transcript was coded based on whether participants' values integrate with CSR-related information for purchases made for both themselves and for others (i.e., gifts). The coding resulted in the identification of four segments of consumers discussed in detail in the results section. Secondly, the coding of the transcripts resulted in the identification 
of distinct themes emerging from our interviews. The themes were examined across each segment of consumers in our sample for the purposes of identifying the factors that have the most influence in ultimately determining whether consumers choose to integrate CSR-related information and attributes into their consumption decisions (see table 3 for the relevant themes across each consumer segment). Finally, data was examined to establish if there were any interrelationships between consumer perceptions of CSR activities and proposed consumer segment (see Table 2).

\section{Results}

Overall the interviewees illustrate that CSR plays a variety of roles in their consumption behavior both for purchases they make for their own personal consumption and for purchases made for others. We find that the participants cite a wide variety of CSR activities that firms currently engage in including environmental practices, domestic and overseas labor practices, the development of environmentally-friendly products and charitable endeavors such as donations, community support and cause-related marketing campaigns (see table 2 for a listing of the CSR activities provided by each participant). This is consistent with previous research that suggests the concept of CSR relates to values and personal judgment (Clarkson, 1995). Importantly, we do not find any relationship between a participants' definition of what activities constitute CSR and whether or not the participant engages in socially responsible consumption behavior. For example, within our typology consumers concerned with environmental practices or charitable donations do not uniformly fit into one segment or another. Further, participants in each of the four segments we identify cite considering similar CSR activities as the basis for their decision making. 
The findings section is organized around four consumer segments that are presented with the key themes that differentiate each consumer type. For each of the consumer segments we explore a number of salient issues, including gift-giving as a means to develop awareness, avoidance of socially irresponsible gifts, the perceived credibility of CSR-related gifts and resistance to CSR generated items. These themes are brought to light by using a typology to facilitate interpretation of data (see Table 3). The typology here is used as a tool in interpreting the data to allow complex phenomena to be dealt with in a single construct (Blau and Scott 1962) as well as to stimulate thinking (Mills and Margulies 1980). The four types of CSR-related gift givers are CSR Evangelists, CSR Preachers, CSR Introverts and CSR Resistors. Within the typology there is a continuum of support for CSR-related gifts which will be examined in relation to social value.

\section{CSR Evangelists}

CSR Evangelists evidenced a strong belief in the value of including CSR-related products for their own personal consumption and similarly for gift purchases. This group of consumers considered CSR-related products to be of higher quality. In addition, these participants also sought to develop greater awareness of CSR activities through a variety of gift purchases including presents during special occasions such as Christmas and for the birth of a child. In this regard these consumers are viewed as CSR Evangelists. For example, the following quote illustrates the confidence and value that buying socially responsible products can provide to consumers for both their own consumption and for gifts:

[Buying products from socially responsible brands] makes me feel like I am doing the right thing. I feel confident that the product is good for me and it's worth 
sharing with my friends and family ... it makes me feel better when I know it's a win-win. (Female, 31)

In addition, some participants suggested that they were willing to pay a premium for socially responsible gifts whether the purchase was for their own use or as a gift based on the perception of a higher quality product. This supports the work of De Pelsmacker et al. (2005) who observe that CSR activities facilitate a willingness amongst consumers to reward companies generating CSR-related items:

You know a [CSR-related] product is better and you know you have to pay a little bit more for something that is socially responsible and it's higher quality...I would rather buy something that is a little more precious to me and I understand why the pricing is higher...A lot of things I want to purchase for me or my friends or to tell them about are made by inspiring companies. (Female, 27)

\section{Gifts as a means to develop awareness}

Importantly, a number of participants who engaged in socially responsible consumption for themselves felt that purchasing socially responsible products for others that do not normally factor CSR into their own decision making was one way of developing greater awareness. This is consistent with Sherry and McGrath (1989) who found that some gifts are purchased with the intent to make the receiver more like the giver of the gift. For example:

If I was going to give a [socially responsible] product to another person, sometimes giving them a product with a CSR value is part of the gift because it is 
something they probably wouldn't buy for themselves so I am buying them corporate social responsibility. (Male, 28)

I actually just sent my dad a box of wine ...The entire box is biodegradable and is great when you go camping so I just sent that off to my dad. It's the French Rabbit company...It actually comes in little juice boxes, it's awesome for camping, it minimizes waste. Their wine is great and the whole thing can be recycled. (Female, 31)

Notably, several participants who were supportive of socially responsible organizations felt that incorporating socially responsible gift-giving into special occasions was an innovative way of introducing friends and family members to the concept. For example:

Last Christmas my entire family bought only previously used or a fair-trade type gift; that's all we bought for Christmas for each other....yeah actually two years running now. So I bought stuff from Ten Thousand Villages and everything else I bought was used. It was great...it was amazing what we were able to find. This year, we are doing something similar. (Male, 32)

A number of participants also felt that they could introduce the concept of socially responsible goods and services to friends and family members who did not currently factor CSR into their purchases through gifts for their young children and babies. This is pertinent as Thomsen and Sørensen (2006, p. 907) note how consumption objects contribute (on a symbolic level) to consumers' transitions between stages in their life cycle. As a consequence, it is more likely that CSR-related gifts in this context will induce a change in future buyer behavior for the 
recipient which, in turn, will have positive implications for companies offering CSR-related products:

I have to buy a stroller for a friend who is having a baby and I am going to get it from Mountain Equipment Co-op (retailer in Canada) rather than other dubious sources and I undoubtedly will pay a premium for that. (Male, 37)

And some of the gifts I sent for a baby shower are from a small, local, boutique shop from my area versus going to a Target or something like that. I was able to find unique gifts and probably paid a little more than I would have at Target but it was soft, organic cotton and hand-made little blankets. (Female, 31)

These CSR Evangelists illustrated not only that they would pay a premium for CSR-related products for themselves but valued these items to such an extent that they identified a number of gift-giving opportunities to communicate their views and induce CSR purchase decision-making attributes in others. These consumers differed from the CSR Preachers as they purchased CSR-related items for themselves as well as purchasing gift items.

The CSR Preachers

CSR Preachers appear to be counter-intuitive in their gift-giving consumer behavior. That is, this type of consumer indicated that although they purchased socially responsible gifts for others they did not differentiate based on CSR-related information for their own personal consumption decisions. In this way, this group were cognizant of CSR-related products but 
considered that CSR issues should be the concern of others. Subsequently Preachers chose to integrate CSR-related information into gift purchases versus personal consumption decisions. Belk (1984, p. 757) notes that one way a gift giver can receive satisfaction is "through the successful presentation of self-communicated characteristics of the gift selected." Consistent with Belk's assertion, several participants in this segment suggested that purchasing socially responsible gifts was based on supporting the social and environmental issues that the recipients' value, even if they do not personally support it. This is also consistent with previous research examining the consumer response to CSR. Specifically, Youn and Kim (2008) posit that consumers seek to present themselves positively to others through the purchase of products from a firm that supports social causes. Further, Yoon and colleagues (2006) note that consumers may base the decision to purchase goods from socially responsible companies in an effort to gain affiliation with reference groups. The following quotes illustrate the desire of the gift giver to be viewed positively based on purchasing socially responsible gifts:

I know that some people think that Body Shop does great work so buying them something from the Body Shop would therefore show that you support their liking the Body Shop and support whatever [CSR activity] they support. (Female, 51)

[Buying] more of what [the gift recipient] actually wants versus a personal value...there are people in my life that I know are extremely socially conscious so I do tend to give them gifts that are more socially conscious than I would normally purchase for myself. (Male, 27) 
Basil and Weber (2006) also note that consumers who have a strong concern for appearances make purchases from socially responsible organizations when attempting to make a positive impression on others. They also suggest that "these individuals may be supportive of CSR because it is the socially appropriate behavior, rather than out of a personal sense that CSR is important" (Basil and Weber 2006, p. 68). Consistent with Basil and Weber (2006), interviewees suggested that they purchase socially responsible gifts as a way of managing their impressions with the gift recipient, even without supporting similar products in their own consumption. For example,

I would probably grab a bag of coffee off the shelf at Fortino's [a grocery chain], for example, for myself. I could think of at least a handful of friends that I wouldn't do that for. I would get the fair trade coffee. I have this love-hate thing with the fair trade label, but for them... it's facilitating the social interaction. (Male, 25)

Probably buying for others, actually...function is diminished [in importance] a little bit. You don't necessarily know specifically what they might be looking for. And because of that then you bring in another category of value - social responsibility. So it's not just function... it's also produced socially responsible. It's like a story with the gift. So when you're giving it to someone, you're saying, "Here's why it's good, you understand the function, and on top of that... here you go, it's socially responsible." But for myself...I don't need to have a story.

(Male, 27) 
Interestingly, the desire to build awareness of CSR activities and socially responsible products was also evidenced by consumers who did not personally support CSR activities. For example, one participant noted that despite not actively supporting charitable causes through personal donations, she attempted to raise awareness of a corporate-sponsored charity drive that provided funds to the local hospital:

At our wedding for example, instead of doing wedding favors, we donated money to the local children's hospital (in our guests names) and ever since then I have encouraged people to do that... it was a very important decision and one that both my husband and I felt good about versus giving boxes of jelly beans to our guests. (Female, 27)

In addition, despite not integrating CSR-related information into personal consumption decisions, another participant also noted the importance of building awareness of CSR-related activities, specifically amongst future generations of consumers:

When I think about it for Christmas presents, sometimes I will buy things from Ten Thousand Villages which is fair-trade; I like to put in things from there for everybody. I probably think more about that when buying for other people which is not really right, it should be for me too... It sounds weird because I am not necessarily buying the stuff for myself, but I like my nieces and nephews to be aware of these things even though I am mostly buying it for them and not myself so yeah just to make them aware. I might put in a card that they have at Christmas saying how you can purchase products from people in poorer countries. (Female, 51) 
Based on follow-up discussion and field notes, this participant suggested that a desire to build awareness of CSR-related products such as fair trade was due to a perceived inequity and the experience of guilt:

People deserve to be paid what they deserve or at least a fair living they can live on and I know we take advantage of a lot of countries and don't provide that standard of living (Female, 51).

Notably, this consumer suggested that the guilt associated with not factoring in CSRrelated attributes for their own personal consumption was somewhat alleviated through the purchase of socially responsible gifts. This finding contributes to recent research that suggests while consumers indulge in 'ethical' and 'unethical' behavior they will seek to compensate for any unethical decision-making (Gregory-Smith et al. 2013). Gregory-Smith and colleagues indicate that guilt is the most salient emotion in the context of decision-making in their study, and that consumers employ guilt-management strategies to both manage cognitive dissonance and explain contradictory behavior. In this respect, while CSR-related items were purchased by CSR Preachers their gift-giving reflected a 'do as I say, not do as I do' attitude. These gift-givers are akin to the 'Socializer' identified by Otnes et al. (1993, p. 236) where "a specific gift becomes an instrument of learning." Although interestingly, this practice also allows the giftgiver to assuage any guilt for (un)related purchases.

\section{Avoidance of socially irresponsible gifts}

Previous research finds that socially irresponsible behavior (CSiR) typically has a much greater impact on consumers' attitudes than CSR activities. In addition, consumers often punish firms that they perceive as unethical despite not being interested in supporting firms they 
perceive as ethical (Creyer and Ross Jr. 1996). Similarly, the final theme that emerged for this segment that do not place emphasis on CSR attributes into their own personal consumption was a desire to impression manage based on avoiding retailers and firms that have reputations for engaging in socially irresponsible behavior (CSiR). For example:

Since my mother hates Wal-Mart, I wouldn't go to Wal-Mart to buy her a gift so yes, if they have a negative connotation, yes I would [make a different decision] but for myself I don't differentiate as much between responsible and irresponsible companies. (Male, 26)

If [my purchase] was for a friend that was really hardcore fair trade and they would absolutely freak out if it wasn't fair trade. Then I would get fair trade because I wouldn't want to hear about it. (Male, 27)

It is clear that these findings support the notion that there are 'easy' and 'difficult' recipients of gifts (Otnes et al. 1993) and that the purchase of CSR-related products can be used for 'difficult' recipients. These gift-givers use CSR-related products to manage the impression the recipients have of them supporting the work of Segev et al. (2012). In addition, the consumers in this segment receive satisfaction from communicating what they believe to be socially appropriate behavior. The next segment we introduce, the CSR Introverts, differ from the CSR Preachers as while they practice socially responsible consumption behavior, they do not convey this in their gift-giving. This however, does not mean that the CSR Introverts are less concerned with impression management than the CSR Preachers, rather that the perception of purchasing CSR-related gifts varies. 
The CSR Introverts

CSR Introverts were notable because of their strength of feeling and personal consumption of CSR-related products which did not translate into gift-giving behavior. That is, a number of participants suggested that they factored CSR-related information into their own personal consumption but actively chose to avoid purchasing socially responsible gifts. The participants noted a number of factors including the role of impression management with the recipient and the perceived lack of credibility of socially responsible gifts as reasons for their behavior. Notably, Oberseder and colleagues (2011) include the influence of peer groups as a factor that determines the consumer response to CSR. They observe that friends and family can both encourage and dissuade consumers to support firms that engage in CSR while also directly influencing the decision as to whether to include CSR as factor to consider in their purchases. The following quote illustrates the influence that friends and family members have on gift-giving decisions that resulted in the decision to avoid giving a socially responsibly gift:

Well, I would like to say yes, I buy socially responsible products for myself and others but there are things that other people value that I don't. (Female, 26)

Based on the accompanying field notes, this participant felt that she had to cater to the tastes of the recipient and often felt she had to avoid products that included CSR-related product attributes that the recipient was not interested in.

Because, some people are not as caring as I am I guess. They don't care as much; they don't make [socially] conscious decisions... you want someone to appreciate 
your gift but if they don't know or don't care, or they think you are too crazy about being socially responsible, they won't like the gift. (Female, 26)

Further, a number of participants suggested that purchasing socially responsible gifts would not be appreciated as much by specific members of their social group and they tailored their gift selection accordingly. For example,

It's just a rough factor of how much I think that they would value having a product from a socially responsible company and whether or not I'm trying to impress that person. Like my brother, I don't think that he would put that much value on [CSR-related items]. (Male, 28)

These findings suggest that although the perception of the recipient is central to the decision-making associated with gift-giving and, while impression management remains consistent for the CSR Introvert and the CSR Preacher, the perception of the recipient receiving a CSR-related gift is considered to vary. This perception of the recipient, for the CSR Introvert, relates to the credibility of the CSR-related item and underscores the significance of the interrelationship between high quality and items generated in using a CSR approach.

\section{Perceived credibility of CSR-related gifts}

Previous research suggests that consumers often perceive the purchase of socially responsible products as requiring a tradeoff between being 'good' and being a high quality product. For example, Griskevicius et al. (2010) suggest that consumers actually give up personal benefits when they choose environmentally friendly products. In addition, Bhattacharya 
and Sen (2004) note that consumers will not respond positively to CSR activities if they have concern that the investment in socially responsible initiatives has detracted from the ability of a firm to produce quality products. Also, Shrum et al. (1995) find that the product's performance is more important than a pro-environmental label when predicting purchase intent. Similarly, participants felt that when purchasing gifts for others, in some instances, socially responsible gifts were not perceived as credible options. For example:

I would be more socially conscious when buying for myself...I try to for other people but I wouldn't let it get in the way of me getting them a good gift. (Male, 28)

Yeah, there are definitely some people that when I buy [socially responsible] stuff for them they look at me like "oh, it's this recycled paper crap...great" and I think, but it's good for you and for the planet. (Male, 34)

The participant also noted that he was frustrated by gift recipients who didn't value the gift and it influenced his future gift-giving decisions. As such, a negative reaction to a CSRrelated gift may also lead to consumers becoming resistant to buying gifts for other recipients in the future.

\section{The CSR Resistors}

CSR Resistors do not factor CSR into either purchase decisions for themselves or for others. Previous research that developed consumer typologies (i.e., Mohr et al. 2001) has similarly identified segments of consumers who were not supportive of CSR activities. The 
current study extends previous efforts by discussing the lack of influence of CSR on personal and gift-giving consumption decisions. These participants provided conventional reasons for not including CSR in their consumption behavior including the belief that socially responsible goods and services were overpriced and that they simply did not have enough information to distinguish the "good" companies in the marketplace. Agreeing with Auger et al. (2008) CSR Resistors are unwilling to sacrifice quality for CSR generated items. For example:

Sometimes you just can't find products that are [responsible] so it's availability ....and sometimes they do cost more and sometimes the variety that is available from those organizations that make those [more responsible] products isn't as good as the other less responsible ones. (Male, 51)

Socially responsible, hmm. Who is socially responsible? I am drawing blanks; that is so sad. I am walking around my house looking at things trying to think of brands that I think are socially responsible. (Female, 27)

In addition, participants also noted that despite placing some value on being a socially responsible consumer, this did not translate into actual purchases, for example:

I like to think that I would [buy CSR products as gifts] and I like to think of myself as a fairly socially responsible person but looking back to my last bunch of purchases, I don't know if I have bought something specifically because there was a positive social image with the company. (Male, 34) 
Importantly for the purposes of the current study, we find that gift decisions were similarly not influenced by CSR-related attributes:

I would have to say no to that because I can't think of any examples. I don't recall when I have had people over (for a dinner party) or bought any gifts when I made any different decisions or purchases versus my own. (Female, 22)

No, I really don't care. I think charity is a personal thing...That's really the final answer because somebody who comes in and judges a gift based on [CSR] wouldn't be invited to my house in the first place.

Finally, one participant noted that price was a bigger consideration compared to CSR activities of firms:

I mean on a moral level we should all be shopping at environmentally conscious stores but that the reality is, is if it's going to be cheaper, then more people will go for that and I am probably in that category. (Male, 30)

\section{Conclusions and Implications}

This study explored the consumer support for CSR in a unique context - gift-giving. Despite a rich literature examining both support for CSR activities and gift-giving, previous research has not yet examined these two behaviors in concert. Given the overlap in motives and other decision-making processes between these two behaviors, this represents a significant gap in these respective literatures. Notably, our findings provide both support and contradict previous research in both literatures. For example, our participants engaged in impression management 
efforts when making gift-giving decisions while also factoring in the role of the recipient. Interestingly, we find that in some instances, consumers actively avoided purchasing products from socially responsible organizations and did so with the intention of managing their impressions with the gift recipient. This is counter to previous research that suggests consumers often choose to make socially responsible consumption decisions in efforts to satisfy selfpresentation concerns (i.e., Griskevicus et al. 2010) and provides an important boundary condition to the impression management literature.

Our findings also illustrated that contrary to the assertion of the attitude-behavior gap, consumers who do not hold positive attitudes towards CSR activities for their own individual consumption can and do purchase these items as gifts. The social value associated with such purchases offers an opportunity to integrate CSR information when purchasing gifts. These types of gifts may also allow the gift-giver to assuage guilt for (un)related purchases.

Our research also adds to the CSR literature by extending the examination of behavioral consistency into a new domain. Previous researchers note that consumers do not act uniformly positive or negative on ethical issues (e.g., Peattie 2001). Our examination of the role of CSR in the gift-giving context provides an entirely new - and significant - form of consumer behavior in which consumers' behavioral consistency can be questioned. The decision to engage in socially responsible consumption for oneself but not for others was motivated by a variety of factors including the role of the recipient and a concern over the credibility of socially responsible gifts. Similarly, a number of participants who do not incorporate CSR into their own personal consumption purchased gifts that supported a variety of CSR activities such as eco-friendly and fair-trade products. Our research identifies the underlying processes and motives that lead to inconsistent behavior within the CSR domain. Previous researchers suggest that factors such as 
the perceived cost of ethical behaviors can lead to behavioral inconsistencies (e.g., recycling is widespread, but the use of environmentally friendly cleaners is not). Our research extends these findings by introducing factors such as impression management motives and a desire to introduce an ethical issue to another individual as drivers of inconsistent behavior.

As the current study was exploratory in nature and included a relatively small sample, future research could employ discriminant analysis on large consumer samples in order to better understand the factors that lead consumers to make decisions as it relates to socially responsible consumption both for their own personal use and for others (i.e., gifts) and to explain this inconsistency. For example, while the participants within our sample did not suggest that the closeness of the relationship influenced their gift-giving decisions; previous research (i.e., Ward and Broniarczyk 2011) has suggested that the closeness of the relationship with the recipient does in fact influence gift purchase decisions.

Future research could also explore the extent to which guilt (or a form of compensatory consumption) is relevant in the context of CSR-related gift-giving as this may have implications for marketing communication messages and campaigns. For example, if CSR items are promoted in such a way to attract CSR Preachers, there may be opportunities to increase both sales and awareness of a campaign by alleviating guilt in the advertising content. As we find that consumers in this segment are motivated by both the desire to manage their impression with the gift recipient and meeting the needs of the gift recipient, future research that examines any potential interaction between these factors would be of value. Additionally, future research could test advertising messages that appeal directly to the gift-giver and could offer cross-selling or upselling ideas to further awareness of particular causes (e.g., during Christmas or Thanksgiving). 
Understanding how consumers divest guilt could be further examined in the context of giftgiving and normative behavior.

Consumer support for CSR activities is influenced by a variety of factors such as the fit between the company and the cause (i.e., Barone et al. 2007), the type of product associated with a cause-related marketing campaign (Strahilevitz and Myers 1998), and the attributions consumers make regarding company's engagement in CSR (i.e., Ellen et al. 2006). Future research could examine whether the factors previously explored in the CSR literature still maintain the importance to consumers as it relates to socially responsible gift-giving. For example, do consumers care about the fit between the company and the cause or do they care more about the recipients' support for a specific CSR activity such as fair-trade or organicallygrown products? In addition, previous research suggests that the size of the donation being made in cause-related marketing campaigns influences the consumer response to the campaign (i.e., Grau et al. 2007). While we do not find evidence of the size of the gift influencing our typology, future research can examine whether socially responsible gift-giving is influenced by the monetary considerations. For example, does the size of the donation or the cost of the socially responsible gift influence the consumer response to socially responsible gift giving? This factor could be examined from both the point of view of the gift giver and the recipient.

Furthermore, several participants suggested that they actively selected socially responsible gifts for the purposes of increasing awareness amongst consumers who do not currently consider CSR activities as an important element of their consumption decisions. Future research could examine whether recipients of a socially responsible gift 'accepted' the gifts and became more aware of CSR activities and if the gift from a CSR Evangelist was viewed as more credible than a CSR-related gift from a CSR Preacher. Does a CSR gift generate more word-of- 
mouth discussion (sought or unsought) and what is the conversion rate from non-user to CSR Introvert, Preacher or Evangelist? And what motivates conversion? In addition, it would be interesting to determine whether the gift recipients engage in socially responsible consumption both for personal use and for future gift-giving occasions as a result of the initial gift.

The 2012 Gifting Report notes that gift purchases account for more than $\$ 1$ out of every $\$ 10$ spent at general merchandise, apparel and furniture (GAFO) retail stores. In addition, the US National Retail Foundation estimates that the expenditure on gifts for Christmas to be $\$ 602.1$ Billion in 2013 (National Retail Foundation, 2013). Importantly, several large retailers offer cause-related holiday programs such as Barnes and Noble's Holiday Book Drive that provided over 1.2 million books to schools, non-profits and libraries across the United States in 2011 (Barnes and Noble Inc, n.d.). Our typology provides an opportunity for future research to provide insight into best practices for marketers in order to further awareness of CSR activities that support important social and environmental issues. For example, the CSR Evangelists are potential ambassadors for CSR-related gifts as they not only demonstrate loyalty through their personal consumption of products but via their purchase decision-making for others. Clearly, as observed here, CSR Evangelists are able to identify key transition episodes in consumer life cycles e.g. the birth of a child, to encourage and induce current and future CSR product use as well as behavioral intent. Harnessing this enthusiasm for CSR-related items, organisations could engage with CSR Evangelists via market research panels to facilitate new product development and product testing as well as via social networking sites to promote CSR-related items through testimonials and blogs. Websites such as Shop With Meaning (shopwithmeaning.org) that provide guidance and advice for consumers who are interested in supporting socially responsible companies through holiday gift purchases would benefit from a better understanding of the 
segments within our typology. An issue associated with a lack of awareness of CSR activities and CSR-related information was also cited by informants who chose not to factor CSR into their consumption decisions. Employing CSR Evangelists could also help develop awareness of the benefits of CSR generated items. For example, consistent with previous research, some informants suggested it was difficult to be aware of which products that are produced in a socially responsible manner.

Finally the decision to buy CSR-related gifts in this study was significantly influenced by the recipient and their positive or negative perception of products generated in a socially responsible manner. Subsequently, gift-givers seeking to use impression management techniques viewed CSR-related gifts as positive (CSR Preachers) or negative (CSR Introverts). As CSR Introverts already purchase and consume CSR generated items, converting CSR Introverts to Evangelists (or understanding the barriers to achieving this transition) may also help develop positive perceptions of socially responsible products or services. Similarly inducing trial of CSR products amongst CSR Preachers may also help with the credibility of CSR inspired gifts. Future research that seeks to identify patterns across our segments by examining variables such as demographics, personality traits and values will greatly assist researchers and practitioners alike. In sum, understanding the phenomenon of socially responsible gift-giving is both timely and appropriate and the current research provides an important foundation on which to build from. 


\section{Appendix 1 - Interview Guide}

- What values do you look for when making a purchase decision?

- Thinking of a recent purchase (over \$100), what attributes of the product do you think made the biggest impact on your purchase decision?

- Do you consider CSR attributes when making purchases?

- Name a few organizations that you think are socially responsible.

- What does the organization do that makes them appear to be socially responsible?

- How important is it for you to purchase goods and services from organizations that are socially responsible?

- Are you influenced by friends and family in terms of purchasing goods from socially responsible organizations?

- Do you influence family and friends in terms of referring them to organizations who are socially responsible?

- Are you willing to pay a premium price for goods and services provided by socially responsible organizations?

- Can you think of ways that CSR can add value for consumers?

- Do you make different decisions when you are purchasing goods for yourself versus other people?

- Specifically, do you tend to purchase goods from socially responsible organizations for yourself or for others?

- Can you provide an example of a purchase for someone else from a socially responsible organization?

- What factors did you consider when making the purchase for someone else? 


\section{References}

Arnold, S. J., Handelman, J. M., \& Tigert, D. J. (1996) Organizational legitimacy and retail store patronage. Journal of Business Research, 35, 229-239.

Auger, P., Devinney, T. M., Louviere, J. J., \& Burke, P. F. (2008). Do social product features have value to consumers? International Journal of Research in Marketing, 25, 183-91.

Barnett, M. L. (2007). Stakeholder influence capacity and the variability of financial returns to corporate social responsibility. Academy of Management Review 32(3), 794-816.

Barnes and Noble Inc, (n.d.) Retrieved May 25, 2013 from:

http://www.barnesandnobleinc.com/our_company/community/Holiday_Book_Drive/holi day_book_drive.html.

Barone, M. J., Norman, A. T., \& Miyazaki, A. D. (2007). Consumer responses to retailer use of cause-related marketing: Is more fit better? Journal of Retailing, 83(4), 437-445.

Basil, D. Z., \& Weber, D. (2006). Values motivation and concern for appearances: The effect of personality traits on responses to corporate social responsibility. International Journal of Nonprofit Voluntary Sector Marketing, 11, 61-72.

Belk, R. W. (1982). Effects of gift-giving involvement on gift selection strategies. Advances in Consumer Research, 9, 408-412.

Belk, R. W. (1984).Cultural and historical differences in concepts of self and their effects on attitudes toward having and giving. Advances in Consumer Research, 11, 754-763.

Bhattacharya, C.B., \& Sen, S. (2004). Doing better at doing good: When, why, and how consumers respond to corporate social initiatives, California Management Review, 47(1), $9-24$. 
Blau, P. M., \& Scott, W. R. (1962) Formal organizations: A comparative approach. Stanford, CA: Stanford University Press

Brunk, K.H. (2010) Reputation building: Beyond our control? Inferences in consumers' ethical perception formation. Journal of Consumer Behaviour, 9(4), 275-292.

Carrigan, M., \& Attalla, A. (2001). The myth of the ethical consumer - Do ethics matters in purchase behavior? Journal of Consumer Marketing, 18(7), 560-77.

Castaldo, S., Perrini, F., Misani, N., \& Tencati, A. (2009). The missing link between corporate social responsibility and consumer trust: The case of Fair Trade products. Journal of Business Ethics, 84(1), 1-15.

Clarkson, M.E. (1995). A Stakeholder Framework for Analyzing and Evaluating Corporate Social Performance. Academy of Management Review, 20(1), 92-117.

Cone Inc. (2013). 2013 Cone Communications/Echo Global CSR Study. Retrieved May 25, 2013 from http://www.conecomm.com/stuff/contentmgr/files/0/fdf8ac4a95f78de426c2cb117656b84 6/files/2013_cone_communicationsecho_global_csr_study.pdf

Cone Inc. (2012). 2012 Cone Communications Holiday Trend Tracker, "Consumers unsure if holiday causes promotions are naughty or nice," Retrieved October 20, 2013 from http://www.conecomm.com/2012-cone-holiday-trend-tracker.

Creyer, E., \& Ross Jr., W.T. (1996). The impact of corporate behaviour on perceived product value. Marketing Letters, 7(2), 173-85.

De Pelsmacker, P., Driesen, L., \& Rayp, G. (2005). Do consumers care about ethics? Willingness to pay for fair-trade coffee. Journal of Consumer Affairs, 39(2), 363-385. 
Donoghue, S. (2000). Projective techniques in consumer research. Journal of Family Ecology and Consumer Sciences, 28, 47-52.

Du, S., Bhattacharya, C. B., \& Sen, S. (2007). Reaping relational rewards from corporate social responsibility: The role of competitive positioning. International Journal of Research in Marketing, 24, 224-241.

Ellen, P. S., Webb, D. J., \& Mohr, L. A. (2006). Building corporate associations: Consumer attributions for corporate socially responsible programs. Journal of the Academy of Marketing Science, 34(2), 147-157.

Glaser, B.G., \& Strauss, A.L. (1967). The discovery of grounded theory: Strategies for qualitative research. Hawthorne: Aldine Publishing.

Goldstein, N. J., Cialdini, R. B., \& Griskevicius, V. (2008). A room with a viewpoint: Using social norms to motivate environmental conservation in hotel rooms. Journal of Consumer Research, 35(3), 472-482.

Grau, S. L., Garretson, J. A., \& Pirsch, J. (2007). Cause related marketing: An exploratory study of campaign donation structures issues. Journal of Nonprofit \& Public Sector Marketing, $18(2), 69-91$.

Green, T., \& Peloza, J. (2011) How does corporate social responsibility create value for consumers? Journal of Consumer Marketing, 28(1), 48-56.

Gregory-Smith, D., Smith, A., \& Winklhofer, H. (2013) Emotions and dissonance in 'ethical'consumption choices. Journal of Marketing Management 29 (11/12), 1201-1223.

Griskevicius, V., Van den Bergh, B., \& Tybur, J. M. (2010). Going green to be seen: status, reputation and conspicuous consumption. Journal of Personality and Social Psychology, 98(3), 392-404. 
Guest, G., Bruce, A., \& Johnson, L. (2006). How many interviews are enough? An experiment with data saturation and variability. Field Methods, 18, 59-82.

Haanaes, K., Balagopal, B., Kong, M. T., Velken, I., Arthur, D., Hopkins., M.S, Kruschwitz, N. (2011). New sustainability study: The 'embracers' seize advantage. MIT Sloan Management Review 52 (3): 23-35.

Hoeffler, S., \& Keller, K.L. (2002). Building brand equity through corporate societal marketing. Journal of Public Policy \& Marketing 21(2), 78-89.

Hollenbeck, C. R., Peters, C., \& Zinkhan, G. M. (2006). Gift-giving: A community paradigm. Psychology and Marketing, 23(7), 573-595.

Laroche, M., Bergeron, J., \& Barbaro-Forleo, G. (2001). Targeting consumers who are willing to pay more for environmentally friendly products. Journal of Consumer Marketing, 18(6), 503-20.

Leary, M. R., \& Kowalski, R. M. (1990). Impression management: A literature review twocomponent model. Journal of Personality and Social Psychology, 107(1), 34-47.

Miller, W. L., \& Crabtree, BF. (1992). Primary care research: a multimethod typology and qualitative roadmap. In B. F. Crabtree \& W. L. Miller (Eds.), Doing Qualitative Research (pp. 3-28), Newbury Park, CA: Sage Publications.

Mills, P. K., \& Margulies, N. (1980) Toward a Core Typology of Service Organizations. The Academy of Management Review, 5(2), 255-265.

Mohr, L.A., \& Webb, D.J. (2005). The effects of corporate social responsibility and price on consumer responses. Journal of Consumer Affairs, 35(1), 45-72. 
Mohr, L. A., Webb, D.J., \& Harris, K. E. (2001). Do customers expect companies to be socially responsible? The impact of corporate social responsibility on buying behavior. Journal of Consumer Affairs 35(1), 45-72.

National Retail Foundation (2013). Retrieved October 20, 2013 from http://www.nrf.com/modules.php?name=Pages\&sp_id=1140.

Oberseder, M., Schlegelmilch, B. B., \& Gruber, V. (2011). Why don't consumers care about CSR? A qualitative study exploring the role of CSR in consumption decisions. Journal of Business Ethics, 104, 449-460.

Otnes, C., Lowrey, T.M., \& Kim, Y.C. (1993). Gift selection for easy and difficult recipients: a social roles interpretation. Journal of Consumer Research, 20(2), 229-244.

Parsons, A. G. (2002). Brand choice in gift-giving: recipient influence. Journal of Product and Brand Management, 11(4), 237-249.

Peattie, K. (2001). Golden goose or wild goose? The hunt for the green consumer. Business Strategy and the Environment, 10, 187-199.

Peattie, K., \& Crane, A. (2005). Green marketing: Myth, legend, farce or prophesy? Qualitative Marketing Research: An International Journal, 8(4), 357-370.

Peloza, J., Loock, M., Cerruti, J., \& Muyot, M. (2012) Sustainability: How stakeholder perceptions differ from corporate reality. California Management Review, 55(2), 74-97.

Peloza, J. \& Shang, J. (2011). How can corporate social responsibility activities create value for stakeholders? Journal of the Academy of Marketing Science, 39(1), 117-135.

Pomering, A. \& Dolnicar, S. (2009). Assessing the Prerequisite of Successful CSR Implementation: Are Consumers Aware of CSR Initiatives? Journal of Business Ethics, $85,285-301$. 
Ratner, R. K., \& Kahn, B. E. (2002). The impact of private versus public consumption on variety-seeking behavior. Journal of Consumer Research, 29(2), 246-257.

Schwartz, B. (1967). The social psychology of the gift. American Journal of Sociology, 73(1), 111.

Segev, R., Shoham, A., \& Ruvio, A. (2012). What does this gift say about me, you and us? The role of adolescents' gift-giving in managing their impressions among their peers. Psychology and Marketing, 29(10), 752-764.

Sherry, J. F. (1983). Gift-giving in anthropological perspective. Journal of Consumer Research, 10(2), 157-168.

Sherry, J. F., \& McGrath, M. A. (1989). Unpacking the holiday presence: A comparative ethnography of the gift store. In E. Hirschman (Ed.), Interpretive Consumer Research (pp. 148-167), Provo, UT: Association for Consumer Research.

Sheth, J.N., Newman, B.I., \& Gross, B.L. (1991). Why we buy what we buy: A theory of consumption values. Journal of Business Research, 22(2), 159-170.

Shrum, L. J., McCarty, J. A., \& Lowrey, T. M. (1995). Buyer characteristics of the green consumer and their implications for advertising strategy. Journal of Advertising, 24(2), $71-82$.

Spiggle, S. (1994). Analysis and interpretation of qualitative data in consumer research. Journal of Consumer Research 21(3), 491-503.

Strahilevitz, M., \& Myers, J. G. (1998). Donations to charity as purchase incentives: How well they work may depend on what you are trying to sell. Journal of Consumer Research, 24 (4), 434-446 
Strauss, AL, Corbin, J. 1990. Basics of qualitative research: Grounded theory procedures and techniques. Newbury Park, CA: Sage Publications.

Szmigin, I., Carrigan, M., \& McEachern, M. G., (2009). The conscious consumer: taking a flexible approach to ethical behavior. International Journal of Consumer Studies, 33, $224-231$

Thomsen, T.U., \& Sørensen E.B. (2006). The first four-wheeled status symbol: pram consumption as a vehicle for the construction of motherhood identity. Journal of Marketing Management 22, 907-927.

Valor, C. (2008). Can consumers buy responsibly? Analysis and solutions for market failures. Journal of Consumer Policy, 31, 315-326.

Ward, M.K. \& Broniarczyk, S.M. (2011) It's not me, it's you: Gift giving creates giver identity threat as a function of social closeness. Journal of Consumer Research, 38(1), 164-181.

Webb, D.J., \& Mohr, L.A. (1998). A typology of consumer responses to cause-related marketing: From skeptics to socially concerned. Journal of Public Policy \& Marketing, $17(2), 226-238$.

White, K., \& Peloza, J. (2009). Self-Benefit versus other-benefit marketing appeals: Their effectiveness in generating charitable support. Journal of Marketing, 73, 109-124.

Wolfinbarger, M. F., \& Gilly, M.C. (1996). An experiential investigation of self-symbolism in gifts. Advances in Consumer Research, 23, 458-462.

Yoon, Y, Gurhan-Canli, Z., \& Bozok, B. (2006). Drawing inferences about others on the basis of corporate associations. Journal of the Academy of Marketing Science, 24, 167-173.

Youn, S., \& Kim, H. (2008). Antecedents of consumer attitudes toward cause-related marketing. Journal of Advertising Research, 48(1), 123-137. 


\begin{tabular}{|c|c|c|c|c|}
\hline Participant & Age & Gender & Occupation & Industry \\
\hline 1 & 30 & $\mathrm{~F}$ & Graphic Designer & Publishing \\
\hline 2 & 27 & $\mathrm{~F}$ & Salon Technician & Beauty \& Well-Being \\
\hline 3 & 37 & M & Business Development & Insurance/Financial Services \\
\hline 4 & 31 & $\mathrm{~F}$ & Owner, operator & Food \& Beverage \\
\hline 5 & 27 & $\mathrm{~F}$ & Administrative Assistant & Healthcare \\
\hline 6 & 51 & $\mathrm{~F}$ & Assistant & Healthcare \\
\hline 7 & 31 & $\mathrm{~F}$ & Occupational Therapist & Healthcare \\
\hline 8 & 22 & $\mathrm{~F}$ & Communications officer & Architecture \\
\hline 9 & 30 & $\mathrm{~F}$ & Graphic Designer & Education \\
\hline 10 & 32 & M & Director of Communications & Education \\
\hline 11 & 26 & $\mathrm{~F}$ & Financial Planner & Financial Services \\
\hline 12 & 27 & M & Consultant (Unemployed) & Finance/Accounting \\
\hline 13 & 28 & M & Unemployed & Financial Services \\
\hline 14 & 30 & M & Travel Agent & Tourism/Travel \\
\hline 15 & 28 & M & Project Manager & Healthcare \\
\hline 16 & 43 & $\mathrm{~F}$ & Account Manager & Insurance/Financial Services \\
\hline 17 & 51 & M & Professor & Education \\
\hline 18 & 38 & M & Manager & Insurance/Financial Services \\
\hline 19 & 43 & M & Communications Professional & Public Services (Library) \\
\hline 20 & 25 & M & Researcher & Non-profit \\
\hline 21 & 27 & M & Fundraiser & Non-profit \\
\hline 22 & 32 & M & President & Financial Services/Insurance \\
\hline
\end{tabular}




\begin{tabular}{cccll}
\hline \multicolumn{2}{l}{ Table 1 } & Interview Sample Demographics & & \\
\hline Participant & Age & Gender & Occupation & Industry \\
\hline 23 & 31 & F & Finance Manager & Pharmaceuticals \\
24 & 34 & M & Researcher & Professional Services \\
25 & 57 & M & Research Assistant & Consulting \\
26 & 27 & M & Entrepreneur & Land Development \\
27 & 34 & M & Marketing Communications & Technology \\
28 & 47 & F & Director & Healthcare \\
29 & 47 & F & President & Food Distribution \\
30 & 38 & F & Director, Health Services & Healthcare \\
\hline
\end{tabular}




\begin{tabular}{|c|c|c|}
\hline Participant & Consumer Segment & CSR Activities \\
\hline 1 & Introvert & Fair-trade products, women's rights and education, self-esteem advertising \\
\hline 2 & Resistor & Fair-trade coffee and foods products, and environmental issues \\
\hline 3 & Evangelist & $\begin{array}{l}\text { Organic foods, locally-produced foods, overseas clothing production (no sweatshops), } \\
\text { community involvement }\end{array}$ \\
\hline 4 & Evangelist & $\begin{array}{l}\text { Fair-trade, small business support, artisan products, organic cotton, organic toiletries, free- } \\
\text { range, organic foods }\end{array}$ \\
\hline 5 & Preacher & Environmental practices, hybrid technology, cause-related marketing \\
\hline 6 & Preacher & Hiring disadvantaged people, community support, fair-trade, environmental issues \\
\hline 7 & Evangelist & $\begin{array}{l}\text { Local food, community involvement, organic clothing, locally-owned business, fair labor } \\
\text { practices, cause-related marketing }\end{array}$ \\
\hline 8 & Resistor & $\begin{array}{l}\text { Charitable support, cause-related marketing, locally-produced clothing, organic foods, BPA- } \\
\text { free plastics }\end{array}$ \\
\hline 9 & Introvert & $\begin{array}{l}\text { Cause-related marketing, ethically-produced clothing, locally-owned business, fuel/energy } \\
\text { efficiency, overseas labor practice }\end{array}$ \\
\hline 10 & Evangelist & $\begin{array}{l}\text { Locally produced clothing, ethical advertising practices, overseas labor practices, human } \\
\text { rights support }\end{array}$ \\
\hline 11 & Introvert & $\begin{array}{l}\text { Eco-friendly products, fair trade, environmental practices, cause-related marketing } \\
\text { campaigns, local community support, organic foods }\end{array}$ \\
\hline 12 & Preacher & $\begin{array}{l}\text { Cause-related marketing campaigns, economic responsibility (i.e., no bailouts), charitable } \\
\text { trusts, child labor, environmental practices/renewable energy }\end{array}$ \\
\hline 13 & Preacher & $\begin{array}{l}\text { Organic foods, sustainability reporting, organic clothing, environmental business practices, } \\
\text { community support, fair trade }\end{array}$ \\
\hline 14 & Resistor & $\begin{array}{l}\text { Environmental issues, pollution standards, emissions, cause-related marketing, socially } \\
\text { responsible investing, hybrid technology }\end{array}$ \\
\hline
\end{tabular}




\begin{tabular}{|c|c|c|}
\hline Participant & Consumer Segment & CSR Activities \\
\hline 15 & Evangelist & $\begin{array}{l}\text { Local business, recyclable products, overseas manufacturing practices, green energy, fair- } \\
\text { trade coffee }\end{array}$ \\
\hline 16 & Introvert & $\begin{array}{l}\text { Environmental practices, over packaged items, reusable shopping bags, minimalist } \\
\text { consumption, cause-related marketing, natural cleaning products and toiletries, child labor }\end{array}$ \\
\hline 17 & Resistor & $\begin{array}{l}\text { Community arts support, corporate donations, corporate sponsorship of education, economic } \\
\text { responsibility (i.e., no bailouts), local foods, }\end{array}$ \\
\hline 18 & Preacher & $\begin{array}{l}\text { Environmental practices, natural resources (i.e., lumber), community involvement, cause- } \\
\text { related marketing, }\end{array}$ \\
\hline 19 & Introvert & $\begin{array}{l}\text { Employee relations, locally-owned business, community engagement, youth programs, } \\
\text { overseas practices, treatment of animals }\end{array}$ \\
\hline 20 & Preacher & $\begin{array}{l}\text { Environmental practices, fuel and energy efficiency, employee treatment, electric car } \\
\text { technology, hybrid technology, misleading advertising practices, overseas labor practices, } \\
\text { fair trade }\end{array}$ \\
\hline 21 & Preacher & $\begin{array}{l}\text { Economic responsibility (i.e., no bailouts), fair trade coffee, corporate donations, local } \\
\text { business, locally produced foods, cause-related marketing, }\end{array}$ \\
\hline 22 & Resistor & $\begin{array}{l}\text { Charitable donations, children's programs, support domestic business, child labor, fair trade, } \\
\text { pollution standards }\end{array}$ \\
\hline 23 & Introvert & $\begin{array}{l}\text { Overseas labor practices, domestic labor practices, recycled products, environmentally } \\
\text { friendly products, retailer recycling practices }\end{array}$ \\
\hline 24 & Introvert & Fair trade, environmentally friendly products, fair employment practices, climate issues \\
\hline 25 & Evangelist & $\begin{array}{l}\text { Environmental practices, cause-related marketing, local charity support, local community } \\
\text { involvement, hybrid technology }\end{array}$ \\
\hline 26 & Resistor & $\begin{array}{l}\text { Cause-related marketing, Product Red campaign, environmental charities, overseas labor, } \\
\text { corporate donations }\end{array}$ \\
\hline 27 & Resistor & Charitable donations, volunteer, work-life balance for employees, green products, overseas \\
\hline
\end{tabular}




\begin{tabular}{ccl}
\hline Table 2 & Participants' Identification of CSR Activities and Segment Membership \\
\hline Participant & Consumer Segment & CSR Activities \\
\hline & & labor, cause-related marketing \\
28 & Resistor & Locally produced, organic food, charitable donations, community support \\
29 & Evangelist & $\begin{array}{l}\text { Charitable donations, environmental issues, organic foods, reusable shopping bags, organic } \\
\text { coffee, low fat menu options, eco-friendly products }\end{array}$ \\
& Resistor & $\begin{array}{l}\text { Charitable donations, reducing emissions, hybrid technology, recycling, food safety } \\
\text { standards }\end{array}$ \\
\hline
\end{tabular}


Table 3 Consumer Typologies

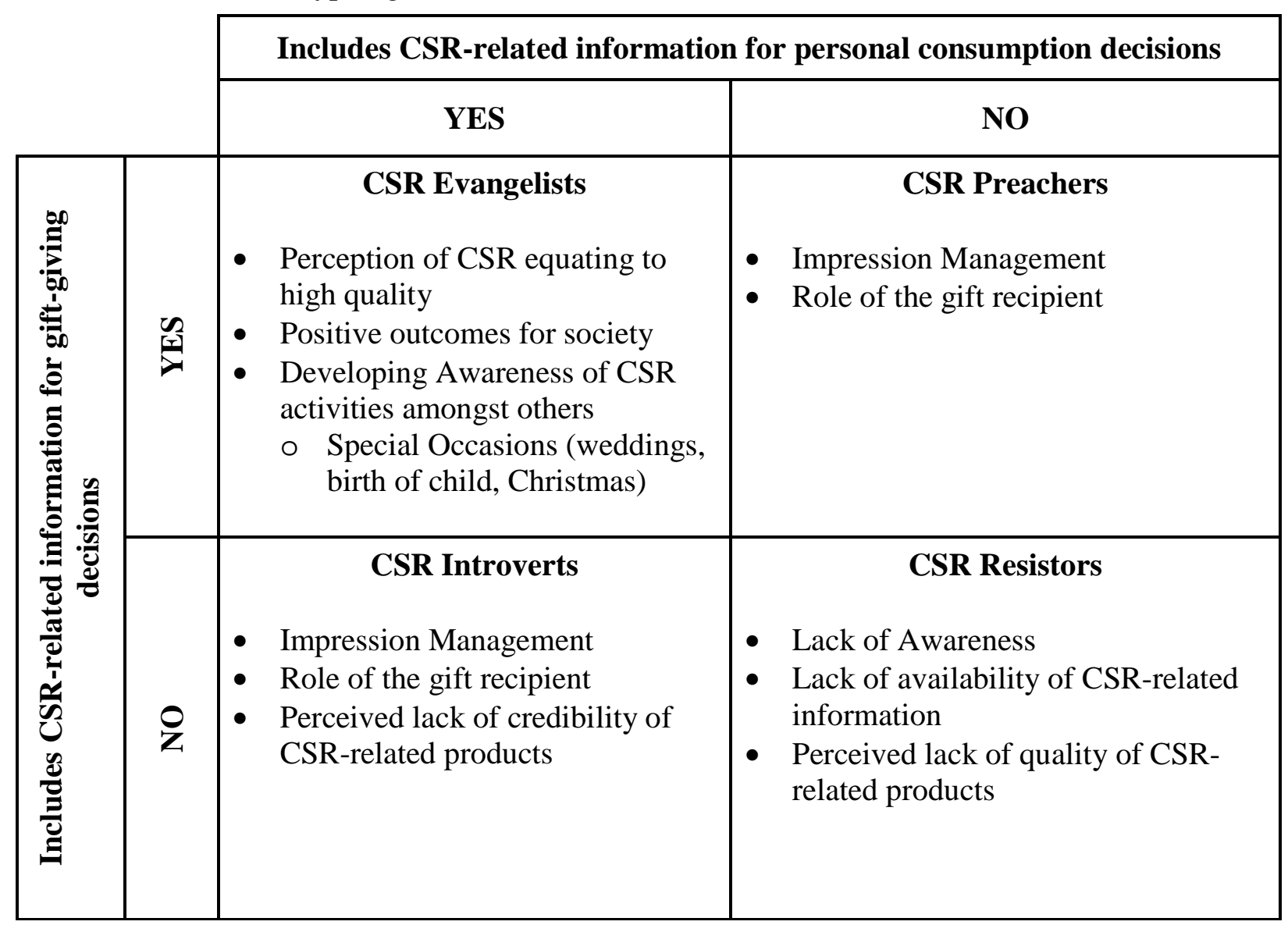

